\title{
The Evolution of Military Medical Services 1854 to 1914
}

\section{Colonel G H Rice}

CD, pcsc, Director of Medical Administration and Resources

Canadian Armed Forces, Medical Branch, National Defence Heaquarters, Ottawa, Canada

SUMMARY: A contemporary examination of the response of Britișh and United States military organizations to the increased manpower wastage occasioned by the diseases and weaponry of war during the period 1854 to 1914 and the resulting changes in how these respective medical services were organized and employed.

The outcome of the First World War in terms of its impact on human life had been accurately forecast in 1899 by the Polish banker Ivan S Bloch when he wrote that "war between the great industrial powers is nothing more than mutual slaughter. The guns direct thick iron rains. The earth is reddened with blood. There will be increased slaughter . . . increased slaughter on so terrible a scale". 1

On the eve of the Great War six to seven million men faced each other on the tortured terrain of Europe or on the oceans of the world. When the Armistice was declared an estimated 8,600,000 men had either been killed in battle or had died as a result of wounds and disease. At least $21,220,000$ others had received war wounds ${ }^{1}$; and of these it was estimated that approximately 75 percent were eventually restored to health ${ }^{2}$.

This achievement did not occur by chance. It was attained largely as a result of the effective response of military medical organizations to the disastrous experiences of the Crimean War and the South African War. Moreover it reflected the response of military organizations to nineteenth-century developments in the fields of science and technology, and to the appeals of a popular humanitarianism that sought to mitigate the horrors of war'.

To comprehend the changes that occurred in military medical services during the period 1854 to 1914 and how they responded to the increased manpower wastage incurred by disease and modern weaponry, it is necessary to examine the developments that affected armies generally. Nineteenth-century progress in science and industrial technology, combined with equally revolutionary social change, altered national military establishments to such a degree that their organization, strategy and tactics and the whole character of warfare were transformed radically.

Demographically there was a lowering of the death rate and an increase in longevity. This situation, occurring as a result of the conquest of disease, improved diets, and active campaigns against infectious diseases, preciptitated enormous increases in national populations ${ }^{4}$. These population increases served to satisfy the manpower needs of industrialized states as well as to provide the human resources necessary to sustain large national armies. Unfortunately the scientific advances that lowered the death rate of civilian populations were not applied as readily to military organizations, and disease, the traditional decimator of armies, continued to plague troops in the field and was generally ignored by military authorities up to the outbreak of the Crimean War5.

Technologically the new inventions and improved methods of manufacture accompanying the Industrial Revolution precipitated the swift expansion of national industries and overseas as well as domestic commerce. These in turn contributed towards a general rise in the standard of living for the civilian populations ${ }^{4}$. From the military point of view, however, the possibility of $\stackrel{\omega}{\omega}$ increased financial and material resources to maintaif the new larger armies that the population explosion now made possible diminished in the face of increasingfy greater cut-backs in defence spending ${ }^{3}$.

Improved transportation and communications such of expanded and improved road networks, railways an 8 the telegraph, while fundamentally serving the needs of the rapidly increasing populations of the new industrialized states, also had an impact on the futurg organization, strategy and tactics of armies. The railways for example, once the intricacies of scheduling movements were mastered, enabled commanders tâ. mobilize and move large bodies of troops rapidly from the interior of a country to a critical border point, or to respond quickly to threats remote from where troops might be garrisoned. They also facilitated the resupply and maintenance of armies in the field once they were deployed. Telegraph facilities not only permitted more effective exercise of command and control of armies but also enabled war reporters for the first time to inform the nation of the impact of war $^{5}$. Developments with direct military application such as the modern bullet, smokeless powder and breachloading small-arms and artillery increased the overall firepower and destructive capabilities of armies and encouraged commanders to respond by devising new methods of employing them in battle.

Politically there was a widespread enthusiasm for colonial expansion which ultimately led to the expansion of European powers abroad and the eventual control of $ᄋ$ more than a billion human beings by a few imperialistic $D$ nations ${ }^{4}$. Colonial expansion also meant military garrisons stationed abroad and this in turn embittered national rivalries. A new meaning was given to alliances $\mathrm{N}$ and ententes and these alignments eventually extended 
the areas of possible international friction. Both statesmen and military leaders were forced to broaden their vision from continental to world politics and inevitably anxiety for national security increased.

The outbreak of the Crimean War saw the British Army with essentially the organization of $1815^{3}$. Chaotic and ramshackle administration prevailed throughout and was, with few exceptions, characteristic of most European armies of the period ${ }^{6}$. Prior to 1854 most European nations had displayed such a penchant for economy that often the only interest taken in military affairs was of an economic nature, despite the fact that as the years wore on the gulf between conditions in civilian life and conditions in the army widened and its organization and administration continually deteriorated.

The medical services of the armies, reflecting the general state of affairs in their organization as a whole, were no exception. During the Crimean War medical services were haphazardly organized and poorly administered. It was generally acknowledged that it was better not to fall sick or be wounded and that a soldier who had been wounded was indeed fortunate should he fall into the hands of a reasonably competent doctor who had a reasonably good place to work ${ }^{7}$. In general the failure to acknowledge the effects of new weapons, to recognize the increased demand for effective means of casualty evacuation, or to apply the concepts of disease prevention that had proven so successful in the civilian population, assured the suffering that was to be the lot of the armies in the Crimea in 1854.

Acknowledging that military medical services are an integral part of any military organization, and that inefficiencies or weaknesses in medical services reflect a similar state of affairs in the larger organization, the Crimean War exposed astonishing weaknesses in the professional armies of the Great Powers which had rusted through long disuse ${ }^{3}$. Up to this time, for example, the British Army had not been trained to operate in any formation larger than a battalion and the medical organization consisted of essentially a regimental medical service only. In the Crimea this same army had initially provided two four-wheeled carts as ambulance vehicles for a force of 28,000 troops but because they were considered to be too big they never reached the theatre and were left behind in Bulgaria. Each British regiment had been issued eight stretchers for the transportation of wounded but there were no trained stretcher-bearers to carry them. Two base hospitals were set up but these were located 300 miles away from the actual battle area. Hospital expenses were still covered by stoppages from soldier's pay. During the campaign, however, chloroform was used extensively for the first time. A Hospital Conveyance Corps was formed to carry wounded from the battlefield and to provide attendants for the two base hospitals. However, this organization consisted only of three officers with the remainder of the Corps being made up of physically handicapped men who inevitably proved to be of little use as stretcher-bearers ${ }^{8}$.

Ultimately disease proved far more disastrous in the Crimea than the guns of Russia ${ }^{9}$. Scurvy became so prevalent that in some regiments hardly a man escaped; dysentery swept the ranks and cholera which had already broken out before the troops landed spread rapidly. Medical supplies were inadequate and the hospitals that existed were verminous, understaffed and overcrowded. Dr Hall, chief British medical officer in the Crimea, reported that "such hospital tents as he possessed had no fire to warm them, the snow drifting in every space, the floors a perfect slough". Most historians have estimated the casualties of this war at approximately one quarter million. The French, for is example, lost 100,000 dead, of whom 75,000 died of $\vec{\circ}$ sickness, the English a total of 20,000 of whom 16,000 died of disease, the Sardinians nearly 2,000 , almost all of whom were victims of disease, the Turks 30,000 , and the Russians 110,000 . Out of every 100 admitted to hospitals 42 died $^{8}$.

The Crimean War evoked a major reaction in Britain and France to the cost of warfare. The telegraph having been used far more effectively by war reporters than generals in the field had brought the message of war home to the nations involved for the first time of Subsequently in 1859 the breakdown of the French medical services following the battles of Magenta and Solferino brought further attention to the importance of military medical services and greater regard was give to the increased manpower wastage resulting from the effects of improved weaponry and tactics.

About the same time in America, rifled weapons and mass armies were producing new horrors which taxe beyond capacity the limited military medical facilities the day. In the American Civil War conditions in field dressing stations were declared as bad as in the Crimea, However, lessons were being learned in the bitter school of experience and military medical services were gradually expanded and improved. In the United States Army of the Potomac for example there was a workable system developed wherein regiments maintained first aid stations from which the wounded were carried by ambulance companies to tented field hospitals. Thence in turn they were transferred to a series of base hospitals outside the war zone ${ }^{7}$. Hospital trains were used for the first time in the American Civil War ${ }^{3}$.

The tremendous increase in war casualties that was to come with the advent of World War One was forecast in several ways by the American Civil War. For example, during the Seven Days Battle, June 25 to July 1, 1862, the South incurred 20,000 casualties and the North 16,000; at Fredericksburg on December 13, 1862, the North incurred 10,000 casualties largely as a result of Confederate artillery fire ${ }^{5}$. Later, during World War $\frac{7}{2}$ One, records maintained by the British medical services showed that the artillery shell alone accounted for fifty or percent of war wounds. In the Civil War it was also 
observed that wherever trench warfare resulted the casualty rates increased. In many instances it became evident to observers that the enormous numbers of casualties inflicted by modern weapons, together with the effects of disease and morale exhaustion, weakened attacking forces at a rate that could not be matched by the supply of fresh replacements.

During the South African War Great Britain again became the subject of unsparing condemnation, and again serious defects were revealed in her army. As the war dragged on its methods became more violent and its conduct more costly, and the loss of life on both sides more severe ${ }^{10}$. The Boer War casualty lists told a terrible tale that gave little encouragement to the nations involved; 6,000 British soldiers were killed, 16,000 died of wounds and disease; 4,000 Boer soldiers were killed, 9,000 women and children died in the concentration camps ${ }^{11}$. Again disease and sickness and not bullets had caused the greater slaughter. Not only had there been a higher casualty list than in any war since the Crimean fifty years earlier but the hostility of much of Europe had been aroused.

In the medical services a number of developments had occurred. The regimental medical services had been abandoned. At the start of the South African War each brigade had a Bearer Company allocated as part of its establishment to evacuate the wounded to the rear and one field hospital to care for them. In addition, each division had a field hospital of 100 beds. Unfortunately, however, these units were all independent of one another and as a result there was no continuity of control $^{12}$. Unification was a logical step and this was accomplished with a new organization, the field ambulance that provided both bearer and treatment functions in one unit under one medical authority. The need for the application of hygiene became apparent and, applying recent developments in medicine, a method of inoculation against typhoid fever was first tried in an army in the field. Sanitary squads were organized for the rear areas and sanitary methods gradually improved. The individual First Field Dressing, adopted from a Prussian idea, was put into use for the first time.

The after-effects of the South African War on the medical organization of armies were many-perhaps the most lasting being the adoption on an official basis by the British Army of the Field Ambulance that was conceived during the South African War and which in various forms has been on the order of battle of Canadian Army units up to the present day. Schools of sanitation were opened in England and were attended by all members of the army. Sanitation was included in officers' qualifying courses. Water testing apparatus was accepted. Staff training was instituted for medical officers following the recognition by the General Staff of the need to train administrative services for war.

During the period 1854 to 1914 it gradually became obvious to military planners that one of the new major problems of nineteenth-century warfare that had to be $D$ faced was how to cope with the increased manpower wastage incurred as a result of developments in technology and science. In military terms this involved $\frac{3}{\infty}$ the development of methods to conserve manpower $\cong$ through the prevention of disease and by timely care of $\delta$ the sick and wounded, not only during battle to free commanders from unwelcome encumbrances and the effect of wounded men on the morale of the healthy, but $\underset{\vec{\rho}}{\vec{P}}$ how to restore these soldiers to health and thence back $\overline{0}$ to duty. One solution that was adopted was the 듬 organization of effective medical services. Another was $\overline{\bar{m}}$ the development of international laws governing the $\bar{\nabla}$ conduct of war and the status of military medical services within the army organization.

From the time that men began going to war they had $\overrightarrow{0}$ had some concern for their sick and wounded, if not $\vec{\overrightarrow{ }}$ from motives of humanity at least then from prudence, $\stackrel{\omega}{\sigma}$ so that being restored they could fight again. ${ }^{12}$. In this context an efficient medical organization was ultimately recognized prior to the outbreak of World War One as a ? great conserver of manpower. By its insistence on the $\vec{\omega}$ principles and practice of hygiene and disease prevention it had adapted scientific developments to keeping troops healthy and avoiding the wastage the्षf $\vec{O}$ had decimated armies in the past. By applying 을 developments in the techniques of planning and organization similar to those used by the rest of the arme it became possible to estimate the effects of weapons and ${ }_{0}$ forecast the material resources, whether they bs transportation, manpower or medical stores, required to care for the sick and wounded. By utilizing advances i transportation and communication such as the railwa and the telegraph they were able to cope with the increased casualty rates, also by acknowledging th humanitarian concern of national populations for the effects of war, to provide a great incentive to morale by ensuring their presence on the battlefield and thereby $\frac{\mathbb{Q}}{\mathscr{Q}}$ assuring the troops that if they are wounded they will be looked after.

During the First World War it was often said that the nation that could produce the last 100,000 men would win the war. If the military organization of the allied powers had failed to recognize the role played by a military medical service in conserving manpower, and had failed to remedy the errors of previous campaigns, this last 100,000 would have been in hospital and not on the battlefield where their presence turned the scale.

\section{REFERENCES}

1. Baldwin H. W. World War I, New York, 1962.

2. Nichols T B. Organization, Strategy and Tactics of the Army Medical Services in War, London, 1937, 156.

3. Preston R A, Wise S F and Werner H O. Men in Arms, New York, 1962.

4. BENNS F L. European History Since 1870, New York, 1955.

5. ZOOK D H and HIGHAM R. A Short History of Warfare, New York, 1966.

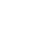


6. BARNETT C. Britain and Her Army, London, 1970, 285.

7. Weigley R F. History of the United States Army, New York, 1967.

8. Clever W G. "The Royal Army Medical Corps" Canadian Army Journal 1954; VIII: No. 3; 10.

9. Ergang R. Europe Since Waterloo, Boston, 1961, 139.
10. LANGer W. K. An Encyclopedia of World History, Boston, 1952, 619.

11. Gilbert M. The European Powers 1900-1945, New York, $1965,11$.

12. MacPhaIl Sir ANDREw. The Medical Services, Ottawa, $1925,67$. 